\title{
Effect of Inkuiri Learning Model on Learning Outcomes Student Primary Teacher Education in Course Learning Civic Education Elementary School
}

\author{
Putri Maharani, Muchtar \\ State University of Malang, Malang, Indonesia \\ e-mail: putri.maharani.fip@um.ac.id
}

\begin{abstract}
This research is based on previous research result about inquiry learning model which shows that inquiry model is able to give positive impact to the development of student potency. Research hypothesis; Ha: there is an increase in learning outcomes and Ho: no increase in student learning outcomes of PGSD by using inquiry model. This research uses quantitative method with pre experimental research because it uses only one class of experiment. The selected sample is one class of student of class of 2014 which acts as a class that gets treatment of Inkuiri model. This research technique used SPSS with t-test data analysis technique. Learning with the model Inkuiri, has been implemented $100 \%$ in accordance with the syntax inkuiri model in the learning subjects Civic Elementary School. The results of the research is the average on the pre test of 53.42 and the post test increased by 6.45 to 59.87 . Based on the results of data processing using SPSS 16, the decision can be taken that Ho accepted and Ha rejected. Thus it can be concluded that there is not an increase in learning outcomes in the course of learning Civics Education by using inquiry model of learning.
\end{abstract}

Keywords: Inquiry, Learning Civics Education, Learning Outcomes.

\section{INTRODUCTION}

Education is the key to the progress of nation and state. Through education, future generations will learn to develop all their potential. This is in accordance with RI Law no. "Education is a conscious and well-planned effort to create an atmosphere of learning and learning process so that learners actively develop their potential to have spiritual power, self-control, personality, intelligence, noble character and skills. Needed him, society, nation and state ".

There are various ways to develop student potential. One is the use of various approaches / models / methods / strategies / media, and so forth. This is important because as a teacher, it should be able to create a conducive learning environment for students so that they can develop their potential. There are several instructional models that are recommended to be used in learning with the curriculum 2013. The learning model is contained in permendikbud 103 years 2014 namely discovery learning, project-based learning, problem-based learning, and inquiry learning.

Research conducted by Narni Lestari Dewi, et al in 2013 with the title Influence of guided inquiry learning model to scientific attitude and science learning result showed that the implementation of guided inquiry model significantly able to improve scientific attitude and the result of fourth-grade student of SDN in Kaliuntu urban village. Another research conducted by Tin Rustini (2009) with the title of application of inquiry model in improving IPS learning in Class IV elementary school also showed that guided inquiry implementation can develop student learning activity. Thus the quality of the process and student learning outcomes is more increased. The existence of the results of the above research shows that the application of guided inquiry learning model was able to improve critical thinking skills, scientific attitude, activity and also student learning outcomes.

The purpose of this study is to describe the influence of Inquiry learning model on the results of student learning S1 PGSD UM. The hypothesis is; $\mathrm{Ha}$ : there is an influence of Inquiry learning model to result in the study of the S1 student of PGSD UM at learning subject of Civic in Elementary School; Ho: there is an influence of Inquiry learning model to result of student study of S1 PGSD UM at learning subject of Civic in Elementary School. 
State University of Malang (UM) as one of the printers of the next generation of educators is one of the educational places that have the goal to develop a professional educator candidate. Therefore, they should be given the best service, one of them with the application of appropriate learning model. Thus, they are expected to further develop their potential.

Learning is essentially a process of continuous activities in order to change learners' behaviors constructively (Hanafiah \& Cucu, 2009: 20). Learning is a process of involving people individually as a whole organism so that there is a change in knowledge, skills, and attitudes (Dimyati, 2009: 156). According to the above view, it can be interpreted that learning is the process of constructing / building thoughts to gain knowledge, skills and attitude changes. It is in accordance with constructivist learning. In the opinion of Hanafiah \& Grandson (2009: 144), the purpose of constructivist learning is "to create a new understanding that demands productive creative activities in a real context that encourages the learner to think and rethink and demonstrate."

Learning is an important factor in the implementation of education. Dimyati (2009: 157) defines learning as a process organized by the teacher to learn the students in obtaining and processing knowledge, skills and attitudes. Based on this understanding can be seen that the actual learning has a goal to learn the students in order to expand their knowledge, skills and attitudes. Surely it is not easy. As a teacher who organizes the learning process, it is supposed to be creative and provide variety in the organization of learning. It is done no other is so that students can develop all the capabilities, both in terms of knowledge, skills, and attitude so that it can be useful for the entire community, nation and state.

The inquiry is a learning model developed by a character named Schuman. According to Suchman in Uno (2009: 14), Suchman believes that children are individuals who are full of curiosity about everything. Therefore, scientific procedures can be taught directly by them.

According to Uno (2009: 14) postulates of Suchman proposed to support the theory underlying the inquiry learning model are: (a) Naturally human beings have a tendency to always find out about everything that interests him; (b) They will realize the curiosity of such things and will learn to analyze their thinking strategy; (c) New strategies can be taught directly and added/combined with the old strategies that students already have; (d) Cooperative inquiry can enrich thinking skills and help students learn about a science that is always tentative and learn to appreciate alternative solutions.

This model aims to train students' abilities and research, explain phenomena, and solve problems scientifically. Because basically intuitively every individual tends to do scientific activities (finding / solving problems). That ability can be trained so that each individual can later perform his scientific activities consciously (not intuitively) with the correct procedure.

Learning using the inquiry model has its implementation steps that include orientation, formulating problems, submitting hypotheses, collecting data, testing hypotheses, and formulating conclusions (Sanjaya, 2011: 201). First is Orientation: The step of orientation is a step to foster a responsive atmosphere or climate of learning. In this step the teacher conditions that students are ready to implement the learning process, by stimulating and invites students to think to solve problems. Some of the things that can be done in this orientation stage are: (a) Describe the topics, objectives, and learning outcomes expected to be achieved by students; (b) Describe the main points of the activities that must be done by the students to achieve the goal. At this stage it describes the steps of inquiry and the goal of each step from the step of formulating the problem to formulating the conclusion; (c) Explaining the importance of topics and learning activities, this is done in order to provide student learning motivation;

Second is Formulate the problem Formulating problems is a step in bringing students to a problem or problem that contains puzzles. It is said the puzzle in the formulation of the problem to be studied because the problem is certainly no answer and students are encouraged to find the right answer. The process of finding answers is very important in the strategy of inquiry, therefore through the process students will gain valuable experience as a mental development effort through the process of thinking. Thus, the puzzle that matters and inquiry is a puzzle that contains a clear concept that must be sought and found. This is important in inquiry learning. Some things to consider in formulating the problem include: (a) The problem should be formulated by the students themselves. Students will have a high learning motivation when involved in formulating issues to be studied. Thus, teachers should not formulate their own learning problems, teachers only provide topics to be studied, while how the formulation of the problem in accordance with the topic has been determined should be submitted to students; (b) The problem studied is a puzzle 
problem with a definite answer, meaning that the teacher needs to encourage students to formulate the problem that the teacher of the actual answer has to say that the student is looking for and finding the answer with certainty; (c) Concepts in the problem are concepts already known by the students. This means that before the problem is studied further through the process of inquiry, teachers need to be sure in advance that students already have an understanding of the concepts that exist in the formulation of the problem. Do not expect students to do the next stage of inquiry, when he did not understand the concepts contained in the formulation of the problem.

The third is Formulate the hypothesis. The hypothesis is the temporary answer of a problem under study. As a temporary answer, the hypothesis needs to be verified. The ability or [the individual's potential for thinking is basically already owned since the individual is born. The thinking potential begins with the ability of each individual to guess or guess (hypothesize) a problem. When an individual can prove it, he will come to a position that can encourage further thought. Therefore, the position to develop the ability to guess on every individual must be nurtured. One way teachers can develop the ability to guess (hypothesize) is to ask questions that can encourage students to formulate a temporary answer or to formulate various possible answers to a given problem. Estimates as hypotheses are not just any estimates but must have a common ground of thinking, so the hypothesis is rational and logical. The ability to think logically itself will be greatly influenced by the depth of insight and the breadth of experience. Thus, any less insightful individual will find it difficult to develop a rational and logical hypothesis.

The Fourth is Collecting data. Collecting data is the activity of filtering the information needed to test the proposed hypothesis. In the inquiry model, collecting data is a very important mental process in intellectual development. The process of collecting data requires not only a strong motivation in learning but also requires the ability and ability to use its thinking potential. Therefore, the task and role of teachers in this stage are to ask questions that can encourage students to think about finding the information they need. Often there is congestion in inquiry when students are not appreciative of the subject matter. Not appreciative is usually indicated by symptoms of lack of enthusiasm in learning. When teachers find these symptoms, they should continually encourage students to learn by giving various types of questions to all students so they can stimulate them to think.

The fifth is Test the hypothesis. Testing the hypothesis is the process of determining the answer that is considered acceptable in accordance with the data or information obtained based on data collection. The most important thing in testing the hypothesis is to seek students' level of confidence in the answers given. In addition, testing the hypothesis also means developing rational thinking skills. That is, the truth of the answer given is not only based on arguments but supported by the data found and can be accounted for.

The sixth is Formulate conclusions. Formulating the conclusions is the process of describing the findings obtained based on the results of hypothesis testing. Formulating the conclusion is the end of the learning process. It often happens because of the amount of data obtained, causing the formulated conclusions not to focus on the problem to be solved. Therefore, to achieve accurate conclusions, teachers should be able to show students what data are relevant.

\section{METHODS}

This research uses quantitative research with experimental research type. This study used quasiexperiments. Sukmadinata (2013: 57) states that experimental research is the purest study because all the principles and experimental rules can be applied in this method. Furthermore, it is also revealed that this method is validation or test is to test the influence of one or more variables against other variables (Krathwohl in Sukmadinata, 2013: 57). The population of this research is all students of PGSD UM. The samples taken are based on draw results. The class that used the research is class D4. Here is the research design used.

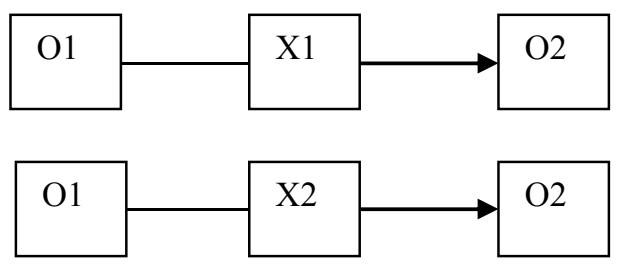

Information:

$\mathrm{O} 1=$ pre-test is given before the learning activity $\mathrm{O} 2$ = post-test is given after the learning activity $\mathrm{X} 1$ = treatment of inquiry learning model for the experimental group

$\mathrm{X} 2$ = treatment of another model for the control group 
The validity and reliability of the instrument are tested using a statistical program. The research instrument used is the observation sheet and the problem along with the key answer. Data collection was done by observation and test technique. This study aims to determine the effect of inquiry learning model in learning activities. Its influence is seen based on student learning outcomes. Therefore, data analysis using SPSS program with data analysis technique paired sample $\mathrm{t}$-test. If $\mathrm{t}<\mathrm{t}$ table, then Ho is rejected. Conversely, if $\mathrm{t}$ arithmetic $>\mathrm{t}$ table, then Ho accepted, with a significance of 0.05 .

\section{RESULT AND DISCUSSION}

This research was conducted for the experimental class using inquiry learning model done on pre test on September 6, 2016. After the pre test was done, the students started to implement the steps according to the accepted model. All inquiry step model inquiry is conducted in class for 3 weeks. Learning activities are implemented $100 \%$ in accordance with the syntax of the model. On the 3rd week, students are also conducting post test to measure the extent of their knowledge development. Therefore post test is held on 18 September 2016.

This table will present pre test results and post tests conducted on the experimental class using Inquiri and control class.

Table 1. Results of Pre and Post Test of Experiment Class

\begin{tabular}{ccccc}
\hline \multirow{5}{*}{ Rlass } & Pre & Post & & \\
& Tes & Tes & Difference & Information \\
Experiment & 53,42 & 59,87 & 6,45 & Naik \\
Control & 50,48 & 54,40 & 3,93 & Naik \\
\hline
\end{tabular}

Table 2 Hasil Pre and Post Tes Kelas with model Inquiry

\begin{tabular}{|c|c|c|c|c|}
\hline Predicate & Up & Down & $\begin{array}{c}\text { Do not } \\
\text { change }\end{array}$ & Total \\
\hline Amount & 29 & 9 & 0 & $\begin{array}{c}38 \\
\mathrm{mhs}\end{array}$ \\
\hline Percentage & $76.32 \%$ & $23.68 \%$ & $0.00 \%$ & $100 \%$ \\
\hline
\end{tabular}

Based on the above table, it can be seen that 29 students in the experimental class with inquiry learning model has increased the score of pre test results against its post test. This result is proportional to $76.32 \%$ of the total members of the experimental class. Meanwhile, there are 9 students or $23.68 \%$ of the results of his post test get a score lower than the pre test score results.

Table 3. Results Pre and Post Class Control Tests with other models

\begin{tabular}{ccccc}
\hline Predicate & Up & Down & $\begin{array}{c}\text { Do not } \\
\text { change }\end{array}$ & Total \\
Amount & 29 & 9 & 0 & $38 \mathrm{mhs}$ \\
Percentage & $76.32 \%$ & $23.68 \%$ & $0.00 \%$ & $100 \%$ \\
\hline
\end{tabular}

The table above shows that the students in the control class who use other models ie the direct learning model that experienced an increase, decrease, and some are fixed score from pre and post test results. In the table, it is also known that the percentage of students who experienced an increase of pre test scores and post test amounted to $54.05 \%$. While students who experienced a decrease in the score of 8 students or $21.63 \%$. Meanwhile, students who have the same result between pre and post test as many as 9 students or equal to $24.32 \%$. The Result SPSS processing data isSig. (2-tailed) 0.512 .

Learning is essentially a process of continuous activities in order to change learners' behaviors constructively (Hanafiah \& Cucu, 2009: 20). Learning is a process of involving people individually as a whole organism so that there is a change in knowledge, skills, and attitudes (Dimyati, 2009: 156). Therefore learning can be interpreted as a physical and psychological process experienced by the learners so that there is a change in knowledge, skills and attitudes.

Meanwhile, learning by Dimyati (2009: 157) interpreted as a process organized by teachers to learn the students in obtaining and processing knowledge, skills and attitudes. Based on this understanding can be seen that the actual learning has a goal to learn the students in order to expand their knowledge, skills and attitudes. As a teacher who organizes the learning process, it should be creative and provide variety in the implementation of learning. It is done no other so that students can develop all the capabilities, both in terms of 
knowledge, skills, and attitude so that it can be useful for the entire community, nation and state.

Students are students who sit in college bench in order to meet certain scholarship. Therefore, PGSD UM students mean college students who sit in universities that are engaged in the science of education in Elementary School. As a student, then they should also be able to develop their capabilities so that they are formed into good citizens. In addition, students of PGSD UM are prospective teachers. Therefore, the learning is aimed to prepare them to become teachers of SD / MI who are qualified undergraduate (S1) who are competent.

One of the determinants of the success of the learning process is the learning model used. The learning model is a series of intact activities conducted in a learning activity from beginning to end. There are hundreds of learning models that can be used. However, not all models can be applied to all subjects, on all competencies / subject matter. One of the models that suit the civic education learning is the Inquiry learning model.

The inquiry is a learning model developed by a character named Schuman. According to Suchman in Uno (2009: 14), Suchman believes that children are individuals who are full of curiosity about everything. Therefore, scientific procedures can be taught directly by them.

The inquiry learning model has the main purpose of helping students to develop intellectual discipline and thinking skills and provide questions and get answers on the basis of curiosity. The inquiry model emphasizes student centered approach. It is said that because in this strategy students hold a very dominant role in the learning process.

As a model of learning, inquiry itself has a special characteristic in its syntax. The inquiry model has the syntax of: (1) orientation, (2) formulating the problem, (3) proposing the hypothesis, (4) collecting the data, (5) testing the hypothesis, and (6) formulating the conclusion (Sanjaya, 2011: 201)

Based on the results of research conducted, pre and post test results indicate that the inquiry learning model is indeed able to bring students more understanding of the concept of learning in Civics
SD. This is obtained from the increase in pre test and post test results from the average class 53.42 to 59.87 with a difference of 6.45 . This suggests that the inquiry model can improve student learning outcomes. In addition, students who experience increased learning outcomes by using inquiry learning model as many as 29 students or equivalent to $76.32 \%$. However, there are also students who experienced a decrease in the results, which amounted to $23.68 \%$ or as many as 9 students. In the meantime, no student experienced the same results between pre and post tests. This further reinforces that the appropriate inquiry learning model is applied to the learning subjects of elementary school.

In order to determine the influence of Inquiry model on student learning outcomes, it can be seen from processed data managed through SPSS. To be able to determine the accepted and rejected hypothesis, there are several things that are known, namely:

The hypothesis proposed are:

Ha: there is an influence of learning result of the student of PGSD by using inquiry model of learning. Ho: there is no influence of student learning result of PGSD by using inquiry model of learning.

Basic decision making:

1. If the value of Significance or Sig. (2-tailed)> 0.05 , then Ho accepted and Ha rejected.

2. If the value of Significance or Sig. (2-tailed) $<0.05$, then Ho is rejected and Ha accepted.

Based on the data table that has been processed by using SPSS above, it can be seen that the significance level of 0.512 so that the result is greater than 0.05 . Therefore, it can be decided that Ho is accepted and Ha is rejected. Thus it can be concluded that there is no difference in learning outcomes of PGSD students by using inquiry learning model and direct learning.

\section{CONCLUSIONS}

Lessons learned in the Civics Learning Elementary School class in experiments have applied $100 \%$ of inquiry learning model. The syntax used is: (1) orientation, (2) formulating the problem, (3) proposing the hypothesis, (4) collecting data, (5) 
testing the hypothesis, and (6) formulating the conclusion.

Based on the research done, the result is the difference of learning outcomes of PGSD students by using inquiry learning model in experimental class and direct learning model in the control class. The average result of the experimental class has a larger gap range of 6.45 . While the difference in average control class is 3.93 .

However, the results of data processing using SPSS 16 revealed that the significance level is greater than 0.05 . Therefore it can be decided that Ho accepted and Ha rejected. Thus it can be concluded that there is no difference in learning outcomes of PGSD students by using inquiry learning model and direct learning.

\section{REFERENCES}

[1] Dimyati \& Mudjiono. 2009. Belajar dan pembelajaran. Jakarta: PT Rineka Cipta.
[2] Hanafiah, Nanang \& Cucu Suhana. 2009. Konsep Strategi Pembelajaran. Bandung:PT. Refika Aditama.

[3] Putu , Arnyana. 2007. Buku Ajar Strategi Belajar Mengajar. Singaraja: Universitas Pendidikan Ganesha.

[4] Sanjaya, Wina. 2011. Strategi Pembelajaran Berorientasi Standar Proses Pendidikan. Jakarta: Kencana Perdana Media.

[5] Sukmadinata, Nana, Saodih. 2013. Metode Penelitian Pendidikan. Bandung: PT. Remaja Rosdakarya.

[6] Syah, Muhibbin. 1999. Psikologi Belajar. Jakarta: PT Logos Wacana Ilmu.

[7] Uno, Hamzah. B. 2009. Model Pembelajaran Menciptakan Proses Belajar Mengajar yang Kreatif dan Efektif. Jakarta: Bumi Aksara.

[8] Wena, M. 2011. Strategi Pembelajaran Inovatif Kontemporer. Jakarta : Bumi Aksara. 